\title{
The Coaching of Private Senior High School of Sport and Student Education \& Training Center in Lampung Province
}

\author{
Jurya $^{1}$, Tandiyo Rahayu ${ }^{2}$, Hari Amirullah ${ }^{3}$, Setya Rahayu ${ }^{4}$ \\ \{juryaunnes@gmail.com ${ }^{1}$, tandiyorahayu@mail.unnes.ac.id ${ }^{2}$ \} \\ Sekolah Tinggi Keguruan dan Ilmu Pendidikan Dharma Wacana Metro, Jalan Seokarno Hatta \\ Mulyojati 16C Kota Metro, Lampung ${ }^{1}$; Universitas Negeri Semarang, Jalan Kelud Utara III, Semarang 24; \\ Universitas Negeri Yogyakarta, Jalan Karang Malang, Yogyakarta ${ }^{3}$
}

\begin{abstract}
The research aimed at developing context, input, and product between Private Senior High School of Sport and Student Education \& training Center. The method used CIPP design where students, teachers, coaches, and supervisors as the subjects. The data tabulation technique used observation technique, interview, questionnaire, and documentation. By conducting data reduction, data presentation, and conclusion, then they were analysed. The result of the coaching showed 1) the contexts had conformity between its vision, mission, and goal that wanted to be achieved, 2) the input was equipped with the availability of training planning documents and program guidelines, 3) the process was well-scheduled for the athletes by the coach 4 ) the product could increase the quality of athletes. In sum, there were weaknesses and flaws related to the success of both research sites. The very basic factual problem lies in the lack of good coordination between agencies and sports stakeholders in Lampung.
\end{abstract}

Keywords: coaching, sport, education, training

\section{Introduction}

National sports management is still less effective and less efficient. There is still no continuity between one sub-system with another sub-system in the context of long-term guidance (8-12 years). In addition, the foundation of sports development such as the national sports competition system still cannot be implemented properly. Even though sports competition is the root of sports coaching to improve the competitiveness of national sports [1].

The implementation of education by considering the development of intelligence, talents' growth and students' talent is the mandate of law that must be upheld both by the Central Government and the Regional Government. Lampung Province is one of the provinces whose vision and mission in education both formal and informal is in accordance with the law. One of them is by manifesting the establishment of training centers, training for gifted students and sport schools to develop the development of potential students in improving achievement in the sports field, fulfilling the capacity of students who have talent in the sports and the implementation of Private Senior High School of Sport and Student Education \& training Center development [1]. 
Government's efforts are very factual to provide special education services for students with inner capacity, intelligence, special talents, and ability by establishing Private Senior High School of Sport and Student Education \& training Center. It is a big idea that must be done with careful planning and calculation. In other words, system design and programs that begin with a need analysis, blueprint design or program prototype, including the master plan for the development of gifted children education need to be done. The results of the design and development were tested and then revised before officially implemented in Private Senior High School of Sport and Student Education \& training Center in Lampung [2].

The head of Lampung Secondary and Higher Education Division stated that the Sports Cultivation School is needed in the region because this area has huge potential athletes, but they are not well educated and trained. Therefore, the presence of the school as well as the training center is expected to bring new athletes in various sports that can bring and raise the name of this area in various sports events.

The formation background of Private Senior High School of Sport in the beginning sports training, especially students, was carried out by the Regional Office of the Ministry of National Education [2], but after regional autonomy responsibility was given to the Regional Education and Culture Office. Through the sports field, good potential areas are given the authority to form Private Senior High School Lampung. The sport branches that include in Private Senior High School of Sport are depending on the potential of superior sports there.

The Private Senior High School of Sport and Student Education \& training Center are pioneer programs for long-term training in sports achievements in Lampung Province. Private Senior High School of Sport and Student Education \& training Center are not running as they should be yet, but the forerunner of accomplished athletes began to develop which cannot be detached from the concept of adequate learning.

There are still a lot of various problems in sports education \& training at Private Senior High School of Sport and Student Education \& training Center in Lampung. Regarding the length of time for the establishment of gifted school sports in Lampung Province, it indicates that sports education and training program in Lampung Province has not run optimally. The problem is the low level in needs of students for sports education and training. Among Lampung residents, there is still the impression that sports education and training are only the property of the people with sufficient economic level because of the high cost. In fact, the success of sports education and training requires the support of all parties, both middle and lower economic communities and above.

\section{Methods}

\subsection{Research Design}

The approach used in this research is a development approach which used qualitative method. This method presents directly the relationship between researcher and informants. The researcher is involved in conducting coaching both to teachers, trainers, and students in the hope that development can improve the achievement. This study used a development research approach with CIPP (Context, Input, Process, and Product) model [3]. 


\subsection{Data Collection}

The research used data tabulation technique to collect data which used observation technique, interview, questionnaire, and documentation.

\subsection{Data Analysis}

After the data were collected, then, they were analysed using non statistic qualitative method.

\section{Results and Discussion}

\subsection{The Context of Students Coaching in Private Senior High School of Sport and Student Education \& Training in Lampung Province}

Context coaching in Private Senior High School Lampung, in the aspect of purposes, showed that the development of Indonesia's future is standardized on Indonesia's long-term vision. The results in context area are 1) there is no conformity between the purpose of Private Senior High School of Sport and Student Education \& Training Center as well as their vision and mission, 2) the implementation of Private Senior High School of Sport and Student Education and Training Center has a strong law and base, 3) the existence of Private Senior High School of Sport and Student Education \& Training Center already in accordance with the needs analysis in each province, in this case, Lampung Province.

The criteria of success for coaching context on the purpose indicator of Private Senior High School of Sport are that there should be conformity between the purpose of Private Senior High School of Sport and Student Education \& Training Center as well as their vision and mission. Based on data checking between the results of the interview and document study, we can conclude that there is no conformity between the purpose of Private Senior High School of Sport and Student Education and Training Center as well as their vision and mission.

The criteria of success for coaching context on the needs analysis indicator is that there should be conformity between Private Senior High School of Sport and Student Education \& Training Center with the existing needs. Based on the data checking between the results of the interview and document study, we can conclude that the existence of Private Senior High School of Sport and Student Education \& training Center is not in accordance with the needs analysis in each province, in this case is Lampung province.

The criteria of success for coaching context on legal base of Private Senior High School of Sport and Student Education \& training Center in Lampung is the existence of a strong legal base. Based on data checking between interview result and document study, we can conclude that the implementation of Student Education \& training Center Lampung has a strong legal base.

In sum, the context of coaching of Private Senior High School of Sport and Student Education \& training Center in Lampung has conformity between its vision, mission, and goal that wanted to be achieved. With a legal base of Private Senior High School of Sport number 800/5166.4III.01/DP.3/2012 and Student Education \& training Center article 25: UU no 3 years 2005. There is the conformity of needs analysis with a background of the existence of Private 
Senior High School of Sport and Student Education \& training Center. It arises because it requires an athlete nursery at the student level.

\subsection{The Input of Students Coaching in Private Senior High School of Sport and Student Education \& Training in Lampung Province}

The coaching plan of Private Senior High School of Sport and Student Education \& training Center in Lampung contained in the curriculum. The curriculum structure is a pattern and arrangement of lessons that must be taken by students in learning activities. It is based on competency standards and subject competency standards determined in credit competency.

The criteria of success for coaching input on the availability of program plans indicator are the existence of training planning documents and program guidelines. Based on data checking between the results of the interview and document study, we can conclude that Private Senior High School of Sport and Student Education \& training Center are equipped with the training planning documents and program guidelines.

The efforts to empower the role of the government, the people community and the business community for the development of sports achievements both in national and regional level cannot be separated from the work of coaching or development of sports achievements quality [4]. Because of that, the empowerment of sports achievements needs attention and care not only from coaches and government but also the people in the community. They can help decreasing the cost of managing matches, coaching and empowering every sporting achievement.

The criteria of success for coaching application on the support of the managing organization indicator are the establishment of good cooperation between existing stakeholders. Based on data checking between the results of the interview and document study, we can conclude that Private Senior High School of Sport and Student Education \& training Center in Lampung have not established good cooperation between existing stakeholders.

The criteria of success for coaching application on the availability of facilities and infrastructure indicator are the availability of adequate facilities and infrastructure. Based on data checking between the results of the interview and document study, we can conclude that Private Senior High School of Sport and Student Education \& training Center in Lampung get the support of inadequate facilities and infrastructure.

The criteria of success for coaching application on the availability of funds indicator are the availability of funds. Based on data checking between the results of the interview and document study, we can conclude that Private Senior High School of Sport and Student Education \& training Center in Lampung got financial support from the state budget, sectoral funding sources, regional general allocation funds, and other self-help funds.

Student Education \& training Center, the head and the branch, got from State Budget as the source of fund. The task of financial management includes three phases; they are financial planning, implementation, and evaluation. Financial planning is an activity related to the available resources. The implementation of the fund is an activity based on plans that have been made and possible to be adjusted if needed.

The Private Senior High School of Sport Lampung is equipped with the availability of training planning documents and program guidelines. The implementation of Private Senior High School of Sport and Student Education \& training Center in Lampung is supported by Education and Culture Office. They have not supported by Youth and Sports Office and KONI yet. Furthermore, the availability of facilities and infrastructure get funding support from State Budget, sectoral funding sources, regional general allocation funds, and other self-help funds. 


\subsection{Process of Students Coaching in Private Senior High School of Sport and Student Education \& Training in Lampung Province}

The coaching process in Private Senior High School of Sport was well-scheduled for the athletes by the coach. The exercise is held $2 * 45$ minutes per day per week. The training hours are included in the learning hours in school. Sundays are used for the athlete as break time and family holidays.

Supervision of the coaching program at Private Senior High School of Sport in Lampung is done well all this time. Coaches often get feedback or suggestions for improvement. The results of evaluations can be carried out at the next stage and can be used as an input for changes and improvements [5]. The evaluation material is also used as a material to select or degrade athletes who have no progress during the coaching process.

The criteria of success for the coaching process on the implementation of program indicator are the suitability of the exercise, implementation of the competition, academic enhancement and welfare as stipulated in the provisions in Private Senior High School of Sport in Lampung.

The criteria of success for the coaching process on the supervision indicator are the conformity between the coaching process and the regulations in Private Senior High School of Sport in Lampung. Based on data checking between the results of the interview and document study, we can conclude that there is conformity between the coaching process in Private Senior High School of Sport in Lampung and regulations of Private Senior High School of Sport in Lampung.

The role of the coach in determining an achievement is needed. Because of that, a coach needs to be very determined and involved with the training process to pursue the sport that is his responsibility [6]. Coaches and sportsmen play an active role as the main factor that greatly determines all training activities. The task of the coaches is not only preparing the athletes to join a competition, but also choosing the best athlete. Since the selection system of sportsmen is an essential part, they do not let incompetence sportsmen be chosen [7].

Training principal is the systematic guides and rules related to the training process. It is a basic principle that is specific biologically, psychologically, and pedagogically [8]. Suggesting the principles of practice that must be considered: excessive loading, consistency, specificity, progress, personal characteristics, training conditions, periodization, stable period, and stresses in practice. Besides that, we must pay attention to the principles of practice, variations in training, detraining, and individualization.

The program implementation is in accordance with what was planned in the Private Senior High School of Sport and Student Education \& training Center in Lampung. The supervision process is carried out as a means to evaluate implementation. This evaluation is related to the performance of the athlete, the performance of the coach and manager. The recruitment process is carried out in accordance with the procedures set out in Private Senior High School of Sport and Student Education \& training Center in Lampung.

\subsection{Product of Students Coaching in Private Senior High School of Sport and Student Education \& Training in Lampung Province}

The coaching product in Private Senior High School of Sport for the athlete physical improvement developed very well. Improvement in athlete physic is very considerable and shows the progress that can be used as a good benchmark of the athlete in Private Senior High School of Sport in Lampung. 
The product coaching result is coaching achievement. Achievement is not only seen from the medals acquisition during the championship between Student Education \& training Center in Lampung but also the improvement which includes increased physical/physiological development, technical development, and mental development. This was reflected in the results of the try-out, the try-ins, the championship, and even during the training process.

From the findings and discussions, we can see that the coaching components are the system that connected to one another. The data from the research findings that were evaluated using CIPP provided the weaknesses related to the success of Private Senior High School of Sport and Student Education \& training Center in Lampung Province are still varied. The researcher revealed a very basic factual problem lies in the lack of good coordination between agencies and sports stakeholders in Lampung Province.

Private Senior High School of Sport and Student Education \& training Center in Lampung are able to increase the athlete's ability. The athletes of Private Senior High School of Sport and Student Education \& training Center in Lampung experienced in increasing the physical/physiological development, technical development, and mental development. This is reflected in the results of try-outs, try-ins, championships and even reflected during the training process.

\section{Conclusion}

Based on the findings and discussion on the results of Private Senior High School of Sport and Student Education \& training Center in Lampung, it can be concluded that the data from research findings that were evaluated using CIPP reveal the weaknesses and flaws related to the success of Private Senior High School of Sport and Student Education \& training Center in Lampung Province. The very basic factual problem lies in the lack of good coordination between agencies and sports stakeholders in Lampung Province. 


\section{References}

[1] Agung, S.: Evaluasi Program Pembinaan Intensif Komite Olahraga Nasional Indonesia Sumatera Utara tahun 2009-2012. Jurnal Ilmu Keolahragaan. 15(1): 99-113 (2016)

[2] Depdiknas.: Pembelajaran Cooperative Learning. Jakarta. Kementrian Pendidikan Nasional (2002)

[3] Zhang, G., Zeller, N., Griffith, R., Metcalf, D., Williams, J., Shea, C., \& Misulis, K.: Using the context, input, process, and product evaluation model (CIPP) as a comprehensive framework to guide the planning, implementation, and assessment of service-learning programs. Journal of Higher Education Outreach and Engagement, 15(4): 57-84 (2011)

[4] Sulastusi, DTAS., Syamsu, SS., \& Syah, M.: Peran Dinas Pemuda Dan Olahraga Provinsi Lampung dalam Pembinaan Kegiatan Olahraga Rekreasi. Jurnal Hima Han, 5(1) (2018)

[5] Badu \& Syamsu, Q.: The Implementation of Kirkpatrick's Evaluation Model in The Learning of Initial Value and Boundary Condition Problems. International Journal of Learning \& Development, 3(5): 74-88 (2013)

[6] Nugroho, W. A.: Pembinaan Prestasi Olahraga Sepakbola Di Pusat Pendidikan dan Latihan Putra Batang. Jurnal Olahraga, 2(2): 162-173 (2017)

[7] Jatmoko, A., \& Yuliani, F.: Peran Dispora Provinsi Riau Dalam Meningkatkan Prestasi Atlet Pusat Pendidikan Dan Latihan Olahraga Pelajar (PPLP). Jurnal Online Mahasiswa (JOM) Bidang Ilmu Sosial dan Ilmu Politik, 4(2): 1-11 (2017)

[8] Hanif, AS.: Evaluasi Terhadap Sekolah Khusus Olahragawan SMP/SMA Ragunan Jakarta. Jurnal Cakrawala Pendidikan, 2(1): 243-255 (2011) 